Session 2005-2109

\title{
Developing Resources for Aligning K-12 Engineering Education to State Education Standards in Texas
}

\author{
A. Dean Fontenot, John R. Chandler, Robert Waller, Betsy O. Carpenter, \\ Malli Travis and Marti Smith \\ College of Engineering, Texas Tech University/ Birdville Independent School \\ District/ Lubbock Independent School District.
}

\begin{abstract}
This article discusses the efforts of the Texas Tech University College of Engineering to provide engineering resources, content, and training for K-12 teachers that meet standards mandated by the Texas Education Agency. In the summer of 2004, we brought in a consultant to work with nine area public school teachers (elementary through high school) to align our Pre-College Engineering/Architecture Academy (PEAP) curriculum with the Texas Essential Knowledge and Skills (TEKS). One result of the workshop is an eight volume set of Engineering Resources for the TEKS and a plan to vertically and horizontally align engineering curriculum within a group of schools in area of Lubbock with predominate populations of low-income African-American and Hispanic students. To support this Engineering Resource Guide and to help teachers introduce engineering concepts and skills to their students, TTU Engineering students act as mentors and facilitators in the K-12 classrooms. These student mentors work in the classrooms of teachers that have participated in a Pre-college Engineering/Architecture Academy Program (PEAP) professional development workshop. The benefits are three-fold: 1) The teacher has someone with engineering knowledge and TTU Engineering faculty contacts, in the classroom; 2) The K-12 students have role models they can relate to; and 3) The University students get mentoring experience, community service experience, and the satisfaction of making a positive contribution as role models to students who otherwise rarely have an opportunity to interact with the college community. This paper will be coauthored by members of the team that participated in this program, and will look at the development of the K-12 Engineering Resources from the perspectives of the public school teachers, the student-mentors, and from program administrators in the TTU Engineering Dean's Office.
\end{abstract}

\section{Overview}

A significant emphasis that emerged from the 2004 Leadership Workshop on K-12 Engineering Outreach, hosted by ASEE, was the need for states to adopt standards for engineering education. Massachusetts's Department of Education has led the way by being the first state to adopt engineering into the core curriculum for K-12 education by enacting state standards for engineering ${ }^{1}$; and although other state education departments have engineering listed as part of their curriculum inventory-Texas Department of Education (TEA) lists Engineering Principals I and II-the classes are traditionally instructional technology courses that do not necessarily include concepts and skills that

Proceedings of the 2005 American Society for Engineering Education Annual Conference \& Exposition Copyright (c) 2005 American Society for Engineering Education 
define engineering. Increasing the number of students entering engineering colleges and insuring that those students are successful in engineering disciplines depends, in many ways, on the role that higher education plays in providing engineering resources to K-12 teachers.

The Association of American Colleges and Universities' National Panel Report, Greater Expectations: A New Vision for Learning as a Nation Goes to College, notes that "Most colleges do not share with secondary schools what they expect incoming first-year students to know and be able to do to succeed in college. Nor do they make clear to college-bound students why the expected preparation matters"1. Texas Tech University is addressing these issues by working with K-12 teachers and administrators to develop the engineering resources, content, and training for teachers so that they will be better prepared to prepare their students, especially women and minority students, for careers in engineering.

By providing engineering resources, content and training that meet state standards for K12 teachers, higher education can make a difference in the number of students applying to engineering colleges and a difference in the success rate of those students.

The analysis of the Leadership Workshop on K-12 Engineering Education shows that $88 \%$ of teachers believe that engineering is important for understanding the world around us; however, only $30 \%$ believe that their students could be successful if they pursued engineering degrees ${ }^{2}$, and most teachers believe that women and minorities have lesser chances of success in engineering than white males.

A significant reason for K-12 teacher attitudes is that very few public or private school teachers have ever taken an engineering course. In fact, most teachers feel that engineering is more difficult than other courses and they probably pass those ideas on to their students ${ }^{2}$, and they are often more comfortable recommending that students seek medical or law professions than engineering professions. Providing resources to teachers that can be integrated into the classroom will not only encourage and help students to prepare for engineering degrees but inform teachers about engineering so that they are more comfortable discussing engineering with students and parents.

Texas Essential Knowledge and Skills (TEKS)

In the 1970's the Texas Legislature mandated that Texas K-12 education institutions measure student knowledge and skills in reading, mathematics and writing. At first students were assessed on minimum basic skills in reading, mathematics, and writing, but in 1990 the focus changed from minimum to academic skills. Ten years later, the legislature mandated that testing should be conducted at more grade levels and be more comprehensive and to include social studies and science. As a result, in 2002-2003 the first set of Texas Assessment of Knowledge and Skills (TAKS ${ }^{\mathrm{TM}}$ ) were administered which "measures the statewide curriculum in reading at Grades 3-9; in writing at Grades 4 and 7; in English Language Arts at Grades 10 and 11; in mathematics at Grades 3-11; in science at Grades 5, 10 and 11, and social studies at Grades 8, 10, and 11" 3 . 
In order to provide K-12 teachers resources that they can actually use in the classroom without jeopardizing how well their students perform on the TAKS, we conducted an eight-day workshop to align our Teacher Training Workshops and other K-12 activities with the Texas Essential Knowledge and Skills (TEKS) standards for each grade level. One primary outcome of this workshop was the creation of an eight volume Teachers Resource Guide with lesson plans that will be available to any schools interested in incorporating engineering content in the future.

\section{Rational for TEKS Resource Guide for Teachers}

The original goal of the Texas Tech University Colleges of Engineering and Architecture was to encourage and assist the Texas Education Agency (TEA) in establishing an engineering teaching certification. While this goal has merit, it would require a great deal of time and expense for TEA and the state. An initial and more achievable goal is to create the Pre-College Engineering/Architecture Academy Program (PEAP) as a K-12 integration of engineering and architecture concepts and skills into the foundational curriculum areas by aligning and correlating the instructional activities to the TEKS, particularly in the science TEKS. This serves two immediate purposes. First, it would provide the application of experiential (hands-on), critical thinking learning experiences that serve as a format to teach the TEKS. A fact that must be accepted is that programs that do not reinforce the TEKS are not considered, much less implemented in most Texas school districts where success of the school district is measured in large part by student performance on the TAKS. Second, it would introduce areas of engineering disciplinary interest from the early school years and create a spiraled system for teaching engineering concepts and skills through high school where more rigorous engineering and architecture learning experiences such as mentor and internships could be implemented. The obvious benefit of better preparing students for collegiate engineering/architecture programs could be realized, and the benefit of presenting these fields as an option for more underserved populations would also be served.

In developing and piloting the PEAP, we have made every effort to reinforce the TEKS objectives as outlined below from the science TEKS:

- provide clear, concise statements of what students should know and be able to do;

- encourage schools to select instructional approaches best suited to their local needs;

- focus in great depth on selected topics at each grade level;

- provide students with the skills to solve complex problems related to the world outside of school;

- provide content depth to ensure students' understanding of science in Grades K12 ;

- move cautiously, but meaningfully, toward a world-class system that develops Texas students as competent, technologically-literate problem solvers.

By using these TEKS objectives and those of the other foundational subject areas, the program could be easily integrated into these core courses at each grade level and meet

Proceedings of the 2005 American Society for Engineering Education Annual Conference \& Exposition Copyright (C) 2005 American Society for Engineering Education 
both statewide educational goals and those of engineering/architectural advocates. The successful implementation of PEAP requires well-planned and professionally conducted staff development workshops on engineering concepts and skills using the developed instructional strategies. This is necessary due to the deficit science preparation of elementary and intermediate educators as well as the lack of knowledge about engineering concepts and career options at all levels.

\section{Process}

With no background in K-12 education curriculum, the College of Engineering program administrators needed to find someone who could bring knowledge of the TEA, the TEKS, and the TAKS to the workshop. At the same time we wanted someone whose background was grounded in curriculum assessment. We found Dr. Betsy Carpenter whose educational assessment experience is extensive and who has been a curriculum consultant for Texas Woman's Univeristy and has sat on Texas Education Agency boards. We paid stipends to nine Lubbock Independent School District teachers to participate in the workshop. The teachers came from elementary, middle school and high school. We are piloting the PEAP at Estacado High School - a predominately minority populated high school - so we have worked with the magnet specialist at Estacado High School to develop four high school courses in engineering: ${ }^{4}$

- Technology in Engineering and Architecture,

- Project Management and Basic Engineering and Architecture

- Product Engineering and Architecture

- Engineering \& Architecture Applications and Professionalism

What emerged from the TEKS workshop is the eight-volume TEKS Teachers Resource Guide. Each grade level has six parts:

- Systems

- Critical Thinking

- Scientific tools

- Communication

- Patterns and Structures

- Technology

Within all six categories, and in almost all of the disciplines, the teachers were able to find ways to integrate engineering concepts, from identifying patterns using DUPLO blocks at the kindergarten level to identifying and managing a complex manufacturing technology project at the high school level.

The teachers were able to find numerous lesson plans on the web that they could include in the resource guide; however, we are now in the process of asking our teachers to contribute their own engineering lesson plans, based on our Lesson Plan Template (Figure 1) to the resource guide in order to circumvent any copyright issues of resources. What this workshop did was take the vast criteria in the TEKS and break it down to manageable size so that teachers can immediately see how engineering can be introduced to students at a relatively young age and in numerous ways. With web sites like TeachEngineering.com, a web-based digital library for K-12 teachers

Proceedings of the 2005 American Society for Engineering Education Annual Conference \& Exposition Copyright (c) 2005 American Society for Engineering Education 
(http://teachengineering.com/) ${ }^{5}$, and the TEKS Teachers Resource Guide, teachers can feel comfortable introducing students to engineering and still prepare their students for the TAKS.

TEXAS TECH UNIVERSITY

Center for Engineering Outreach

Inspiring and teaching tomorrow's engineers.

\section{Lesson Plan Title}

\begin{tabular}{|l|l|l|l|}
\hline Grade Levels: & Grade Levels & $\begin{array}{l}\text { TEKS } \\
\text { Addressed: }\end{array}$ & $\begin{array}{l}\text { TEKS Addressed by } \\
\text { number }\end{array}$ \\
\hline Content Levels: & Content Levels & & \\
\hline
\end{tabular}

\begin{tabular}{|c|c|}
\hline Purpose: & Overview of the goals of the activity \\
\hline Materials: & List of materials used \\
\hline Preparation: & Describe the preparation needed for the activity \\
\hline Activity: & Describe the procedure for the learning experience \\
\hline Evaluation: & Describe evaluation techniques for the activity \\
\hline Extension: & $\begin{array}{l}\text { Describe ways that the experience can be modified or extended for advanced } \\
\text { learners or additional classroom instruction }\end{array}$ \\
\hline Resources: & List resources used by the project \\
\hline
\end{tabular}

Figure 1: Lesson Plan Template

Figure 2 is an example of integrating engineering at the kindergarten level and aligning the lesson with the TEKS by looking at the story of the Three Little Pigs.

Proceedings of the 2005 American Society for Engineering Education Annual Conference \& Exposition 


\section{TEXAS TECH UNIVERSITY \\ Center for Engineering Outreach}

Inspiring and teaching tomorrow's engineers.

Building with the Three Little Pigs
\begin{tabular}{|l|l|l|l|}
\hline Grade Levels: & Pre-K - Kindergarten & $\begin{array}{l}\text { TEKS } \\
\text { Addressed: }\end{array}$ & $\begin{array}{l}2.1,2,3,4,5 \\
3.1,2,3\end{array}$ \\
& & & $6.1,5$ \\
\hline Content Levels: & $\begin{array}{l}\text { Science } \\
\text { Reading }\end{array}$ & & \\
\hline
\end{tabular}

\begin{tabular}{|c|c|}
\hline Purpose: & $\begin{array}{l}\text { Students will learn about building materials and construction modeling } \\
\text { techniques by reading The Three Little Pigs, discussing their reading, and } \\
\text { building a model house. }\end{array}$ \\
\hline Materials: & $\begin{array}{l}\text { The Three Little Pigs } \\
\text { Pictures of construction using different materials } \\
\text { Twigs } \\
\text { Straw } \\
\text { Duplo Bricks }\end{array}$ \\
\hline Preparation: & $\begin{array}{l}\text { Prepare for the lesson by reviewing the story of The Three Little Pigs. Prepare } \\
\text { samples of the twigs, straw, and Duplo bricks that the students can investigate. } \\
\text { Make a bucket full of twigs, straw and Duplo bricks mixed together for } \\
\text { students to sort during the lesson activity. }\end{array}$ \\
\hline Activity: & $\begin{array}{l}\text { 1. Read aloud the story of The Three Little Pigs. } \\
\text { Discuss the story with students: } \\
\text { What materials did the pigs build with? } \\
\text { What buildings fell down easily? } \\
\text { What buildings were strong enough? } \\
\text { What materials do we use to build buildings today? } \\
\text { 3. Show the students pictures of construction projects. Discuss the } \\
\text { projects: How are the different materials used? } \\
\text { 4. Provide students with the mixed materials of straw, twigs, and } \\
\text { bricks. Have the students sort out the building materials. } \\
\text { 5. Lead the students in building a model of their own house out of the } \\
\text { provided materials. }\end{array}$ \\
\hline Evaluation: & $\begin{array}{l}\text { Have the students regroup for an oral journal about the day's experience. Have } \\
\text { each student contribute to the story telling of what they did that day. }\end{array}$ \\
\hline Extension: & $\begin{array}{l}\text { Have students draw pictures or collages of their homes. Discuss how } \\
\text { blueprints are similar and how such drawings are used in construction. } \\
\text { Discuss careers that deal with buildings and construction. }\end{array}$ \\
\hline Resources: & Barbaresi, Nina, illustrator, The Three Little Pigs, Merrigold Press, NY, 1981. \\
\hline
\end{tabular}

Figure 2: Example of Kindergarten Engineering Lesson Plan 
Two of the teachers who participated in the TEKS Workshop have contributed to this paper, and they express best the value that they see in having a resource guide that addresses engineering education and the TEKS objectives:

One of the most important successes for our students has been that these engineering activities are not TAKS formatted. There is no one right or wrong answer. Each activity or challenge allows for individuality. Each activity is different and molded into a specific form. There is no repetition for the students to become restless or bored. The activities keep the kids engaged. The students can find any area where they excel. They may be master builders; they may be better artists for the technical drawings; they may operate a computer beautifully; or they may be a wonderful presenter. Each student can find their own niche. This allows for the students to gain tremendous skills in teamwork to accomplish the same goal. Even though the skills needed for TAKS are important, these engineering activities allow for more problem solving, critical thinking, and creativity on the students' part. They are not tied to a certain form to solve the problem, and they are not tied to one particular answer. The students feel that there is more freedom to incorporate their own knowledge and experience into the solution. Engineering has been a huge motivator for the students to put forth an effort with TAKS so they may participate in these other activities.

TAKS scores on the science tests across the state are extremely low. Science has usually always taken a back seat to reading and math. Looking more closely at the scores, it is also apparent that the physical science strand is the worst performed. Teachers typically stick to the areas that they are comfortable teaching. Life science is where most of the curriculums start so these areas are covered before the crunch of test time approaches. Earth sciences are fun and the students really seem to enjoy them; therefore, the scores in this area are not so low. However, physical sciences are difficult to teach and understand. Engineering helps tremendously with that. The activities are hands-on and demonstrate the laws and concepts of physics. Students are more able to grasp the topic by engaging in hands-on learning than they do by just reading the concepts out of the textbook.

The engineering and robotics activities can be directly tied to many TEKS objectives in not only science, but in the other core curriculum areas. Engineering covers the physical science strand in science as well as some of the objectives in life and earth sciences. As with our Mars exploration activities, all the TEKS for the space can be covered, and if a teacher chooses to get into genetic engineering then some of the life science objectives can be incorporated. Since engineering is the process of applying science and math, then a great majority of math concepts can be covered, especially the measurement objectives that seem to rank in the lower areas of performance. Engineering allows for hands-on activities to show the students how to manipulate tools and measurements. The students stay engaged and retain more of the information than if they were only computing problems on a paper. They see how the ideas of math belong in the real world. 
Language arts objectives are also very easily adapted into the engineering activities. As with all the design challenges, there is always some form of research and presentation. We have found that those language arts objectives that are difficult to cover such as listening, speaking, and critiquing others are easily covered within the engineering lessons. Social studies can even be incorporated by looking at the cultural and historical backgrounds and necessities of engineering developments. As a teacher, to teach smarter is a huge drive for developing lesson plans. By being able to incorporate more than one subject and a variety of TEKS objectives into one lesson, it makes the teacher's job so much easier and allows more time to cover those areas needing more direct instruction.

One of the largest sellers for teachers is that an engineering based curriculum is not pre-programmed. Like the students, we can add our own creativity and teaching styles into the lessons. It also keeps us more motivated. We have to be engaged in the planning of the lesson in order for it to be successful. The activities and lessons are not just written out to be copied off and read. Effort and planning is required that we feel is important for all teachers to stay on the top of their game. The engineering activities are also geared towards problem solving, critical thinking, and creativity. The state stresses these areas as important, but TAKS doesn't really incorporate these ideas. The TAKS is tied to one form with one response. Engineering can lead to a variety of answers all as good as the most obvious answer. Our kids are not learning by just reading and computing. They must do and think, and engineering empowers them to do that.

\section{Copyrighting Issues with the Lesson Plans}

From a publication perspective, the most complex aspect of creating the engineering resource guide was ensuring proper adherence to copyright laws. As a compiled work, the engineering resource guide is a heterogeneous collection of different works, each with its own set of legal publication challenges. Some lessons were written by Texas Tech University employees and possessed an inherent copyright. For other lessons that were found on the Internet or written by contributing teachers, the issue of ownership and right to publish was not as straightforward. In examining all of the different copyright scenarios and securing the right to publish the contributions to the resource guide, staff in the TTU Engineering Dean's Office focused on the provisions of copyright and fair use, licensing works contributed to the resource guide, and licensing future submissions.

Because of the importance of copyright compliance, organizers were forced to examine the provisions of copyright law and the allowances made for fair use in education. It is important to note that regardless of the explicit notice of a copyright, all works fixed in a transmittable form are protected. If a copyright is registered and bears the copyright symbol, $\mathbb{C}$, it is simply easier to prove copyright ownership in a dispute. Therefore all submissions for the resource guide - including websites - did have copyright protection and it was necessary to secure permission prior to publication. 
In addition to the consideration of copyright, there was also a consideration of the terms of fair use. Cited frequently in academia, fair use is a doctrine established in the courts that allows for partial use of copyrighted material, especially in educational applications. While the engineering resource guide is a non-profit, educational guide and we could easily make an argument under fair use, the key consideration is that submissions for the guide included whole websites, not partial contents. While fair use is a gray area in copyright law, most counsel will agree that it is not considered fair use to replicate in whole a copyrighted work. With this realization, it was clear that fair use did not apply to this publication.

After understanding the provisions of copyright and fair use as they applied to the resource guide, it was important to secure content licensing from document contributors. Most contributors fell into one of three categories: teachers currently working on the collaboration project, teachers that had written content for Texas Tech University in the past and authors who had published lessons that we wanted to include in the guide.

For teachers that were currently working to develop the engineering resource guide with Texas Tech University as paid consultants, it was important to determine their licensing status. As consultants working for the university, their contributions to the guide and the copyright of those works are considered work-for-hire and simply required a documented agreement between the university and the consultant identifying their work as a work made for hire. With the work for hire status documented, Texas Tech University retained copyright status on all collaborations the teachers made to that project during their consultation.

In securing copyright for teachers that had previously created content for the university, it was necessary to transfer the copyright that belonged to the author to the university. While this should have been done earlier as a work made for hire, it was impossible to document such a work retroactively. Instead the copyright was transferred from the author to the university using an assignment of copyright form. This document in effect made the university the author of the document instead of the originating teacher and granted the university all rights that are afforded an author under copyright law.

The final and more complicated contribution to license was third-party lesson plans that commonly appeared on websites or in other publications and were not written for the engineering resource guide. Naturally the university had no claim to the copyright of these documents, so instead it was necessary to secure a copyright license from the author. This involved a formal solicitation of permission from the author for permission to use their work. In many cases authors were happy to grant full license of their work given the non-profit, educational nature of the resource guide. Some authors, however, did stipulate conditions under which the university could distribute their work. A few authors did not allow the university to use their material, and such contributions were edited from the resource guide. Also many contributions are pending approval from the copyright owner before they can be published into the resource guide. Such a permissions process is tedious and often long-lived, but it is essential in providing legal protection for the publication of such a compilation. 
Considering the future use of the engineering resource guide it is likely that it will grow as more and more teachers submit lessons for inclusion. With that in mind, the TTU Engineering Dean's Office is looking to license submissions and the documents as a whole using Creative Commons licensing. Creative Commons licensing is designed to promote the free exchange of information while still preserving copyright ownership. In using the Creative Commons license, contributors will acknowledge that their submission can be used in a non-profit, educational setting by the university. Likewise, the resource guide itself will be distributed under a Creative Commons license, allowing anyone and everyone to copy and distribute from the resource as long as they acknowledge the ownership. In this way Texas Tech University can further the free exchange of ideas that is so critical to academia without violating the essential protections of copyright law.

\section{TTU Pre-College Engineering/Architecture Academy Program K-12 Teacher Training ${ }^{6}$}

It is not enough to provide text resources or hands-on activities for the classroom, teachers must be supported in the classroom and students must be given incentives for wanting to learn and apply math and science skills. The College of Engineering provides a wide-variety of high quality enrichment components, such as after-school programs, mentoring and tutoring, classroom demonstrations, campus visits and shadowing, and other activities promoting engineering concepts and skills to K-12 students and teachers. While these enrichment activities provide exciting learning experiences and have dramatically increased interest in engineering, the overarching goal is to motivate and provide more opportunities for students to engage in the rigorous academic preparation necessary to succeed in engineering degree programs.

In summer 2003 we offered two training workshops in the areas of robotics and aeroscience developed by some of these teachers with the help of Tech faculty and graduate students. The workshops allowed us to train approximately 20 teachers from a variety of disciplines and grade levels. The training grounded them in engineering practice and gave them the knowledge and skills to implement engineering content in the existing curriculum for whatever grade levels and subjects they teach. The enthusiasm of the newly trained teachers has led to the schools taking ownership of the program. They have established well-defined academic requirements and operating policies to handle rapidly increasing student demand, and providing much needed structure.

\section{RoboRaider LEGO Training}

We developed the RoboRaider LEGO training program in 2003. Because this training was so well received and impacted such a large number of students, we increased the number of offerings to two workshops in 2004. TTU mentors participated in the week long training as facilitators, as well as got LEGO Robotics training to inform their activities in providing classroom support for K-12 teachers in the upcoming year.

This training contributes to the Pre-college Engineering/Architecture Academy's projectbased curriculum by giving the K-12 teacher/participants hands-on experience in 
developing classroom exercises using programmable LEGO equipment. The teachers applied this training in a Summer LEGO Camp for elementary school students and have developed various activities this school year to engage students in learning about science, technology, engineering, and mathematics. These teachers also participate in follow-up meetings to share experience and receive additional training in short workshops during the school year.

Developing our own content for the RoboRaider training has resulted in several school districts from across the State sending teachers for robotics training. Several of these districts have initiated various activities such as after-school programs with engineering content as result, and some Texas school districts have requested our help in establishing complete TTU Pre-College Engineering Academy programs.

\section{Rocketry Workshops}

We are exploring every opportunity to develop curriculum and content that is useful in teaching engineering concepts and skills, so we were thrilled when Brett Williams, a teacher at Fredericksburg High School, in Fredericksburg, Texas, approached us to help develop and disseminate the exceptional rocketry program that he created. In developing this program, we formed the Texas Partnership for Areoscience Education (TPAE), a consortium that includes Fredericksburg ISD, Texas Tech, Midland College, and Pecos County Spaceport Development, Inc. With contributions from all the partners, a number of exciting educational opportunities have already emerged, and we are developing a rocketry thread that includes three levels of teacher training that will be developed for the Academy program. We hired Mr. Williams to deliver the first level of training to teachers in the West Texas region. The content provides an exciting hands-on approach for teaching physics and mathematics using rockets to illustrate the concepts being taught. TTU mentors helped facilitate the workshop and participated in the training to help further develop this thread as part of the Academy program.

One of the new workshops developed allows teachers to go beyond the training offered in the first rocketry workshop and receive certification by the Tripoli Rocketry Association that allows them to launch larger rockets capable of carrying payloads that can give their students a wider range of engaging learning experiences.

Interest in these workshops has grown so we are offering six summer workshops in 2005, three RoboRaider LEGO workshops and three Rocketry workshops. As we further develop the Pre-college Engineering/Architecture Academy Program, we plan on offering additional engineering tracks such as environmental engineering and workshops to support those tracks.

\section{Student Mentors}

Along with teacher training, we provide engineering students as mentors, as K-12 classroom resources, and as role-models. The student mentors support teachers in the K12 classrooms when classes are engaged in some engineering activity like the LEGO 
Robotics or the Rocketry program. Teachers have said that the mentors make it possible for them to be successful with the hands-on activities because the mentors are not just another person in the room when there is a great deal of activity but that the mentors are able to bring engineering concepts, that the teacher does not know, into the activity. In addition, the student mentors act as role models for the K-12 students, especially the minority students. The majority of our mentors are women or representatives from minority populations. The significance of this is impossible to measure, but K-12 teachers and student mentors have expressed the value that they feel this adds to the minority students' lives. Nestor Vidales, a student mentor, says "The students are always happy to see you, and they really want to learn from the mentors because we are also students." This is the same reaction that most of the mentors have, and they feel that they are actually contributing something important to the classroom and especially to these students' lives. Rebecca Thomason, student mentor, says that she finds "it very rewarding to be able to have a positive influence in their lives, both in energizing them about science and math, and also in serving as a role model to them." At the same time, Rebecca says that it is important for her to earn the students' respect as well as work with their teachers to "teach them values of team work, good listening skills, and encourage a passion for learning."

The student mentors feel they gain as much from the program as the K-12 teachers and students. They obviously gain valuable mentoring experience and community service experience that they can take with them into practice, but they also learn how to communicate with people who are not engineers, work in environments that may not necessarily initially be comfortable, and develop teaching skills. In addition, they get to play a significant role in improving K-12 awareness of engineering and knowledge about engineering.

Some of the student mentors receive outreach scholarships, others are paid as student workers, and some are volunteers. After they get their semester schedules, they work with the College of Engineering Outreach Coordinator who schedules their schools, dates, and times. In addition to classroom activities, they assist with after-school and Saturday programs like RoboRaiders Super Saturdays where elementary students come to Texas Tech to demonstrate their robots to college students. Some of the mentors who work in the summer also develop and teach summer engineering courses that are part of Science It's a Girl Thing - a week-long summer camp for elementary, middle-school, and high school girls.

All of the mentors attest to the rewarding experience that this program offers. They not only get to work with K-12 students and teachers, but they learn more about engineering because they become the teachers and have to share their knowledge with others.

\section{Conclusion}

After five years of trying different approaches for getting engineering content into the K12 public school system here in Texas, we discovered the Teacher Training Workshops were having the most success because teachers are empowered to implement hands-on 
science and math activities in their classrooms, no matter what grade level or subject area. Providing mentors in the classroom to assist them with the engineering activities, providing after-school and summer programs for the students, and providing access to Texas Tech University resources were all valuable, but giving them ownership of engineering course content and then giving them the means in which to align the content to the TEKS has given solidity to the Pre-College Engineering/Architecture Academy Program. We are asking teachers who attend our summer Teacher Training Workshops to submit at least one lesson plan on how they use either the LEGO Robotics or the Rocketry. We continue to develop new K-12 engineering tracks that we can offer at our Teacher Training Workshops, and continue to look for ways to collaborate with other educational institutions in Texas.

We are also in the process of developing tools for assessing our Program and our Workshops. The quality of lesson plans submitted by the teachers will be one means of assessing how teachers are actually applying what they learn in our Teacher Training Workshops. As with any program this size, it will take time to see if we have made a significant impact on students coming out of the Pre-College Engineering Academy Programs, but we know we have teachers excited about participating in the workshops and having access to resources like the TEKS Teachers Resource Guide.

Bibliography

1. Greater Expectations: A New Vision for Learning as a Nation Goes to College. (2002) Association of Colleges and Universities National Panel Report, Washington, DC: 2002.

2. Douglas, J., Iversen, E., and Kalyandurg, C. "Engineering in the K-12 Classroom: An Analysis of Current Practices \& Guidelines for the Future.” (2004) ASEE Engineering K-12 Center, American Society for Engineering Education; 2004.

3. Texas Education Agency. Student Assessment Division. www.tea.state.tex.us/student.assessment/about/overview.html. Accessed 2004 Dec 30

4. Chandler, J. R. and A. Dean Fontenot (2003) "TTU College of Engineering Pre-College Engineering Academy(C) Estacado High School Pilot Program" Proceedings of the 2003 American Society for Engineering Education Annual Conference \& Exposition, American Society for Engineering Education. Session 2253, CDROM, 2003.

5. TeachEngineering.Com: Hands-on Resources for K-12 Educators. http://teachengineering.com/ Accessed 2004 Dec 30

6. Chandler, J.R. and A. Dean Fontenot (2004) "TTU College of Engineering Pre-College Engineering Academy Program (C) Teachers Training Program" Proceedings of the 2004 American Society for Engineering Education Annual Conference \& Exposition, American Society for Engineering Education. Session 2530, CDROM 2004.

A. DEAN FONTENOT, PH.D.

A. Dean Fontenot earned a Ph. D in English at Texas Tech University. She taught English literature and composition for 15 years before moving to the College of Engineering where she is currently the Sr.

Director of Engineering Outreach and Literacy and teaches Engineering Communication in the Industrial Engineering Department. 
JOHN R. CHANDLER, PH.D.

John Chandler earned a Ph.D. in Technical Communication and Rhetoric at Texas Tech University and currently is the Director of Technical Communication for the College of Engineering, and he is the Director of the Center for Partnerships in Science and Technology, which oversees K-16 projects that impact students' understanding of STEM education.

BETSY O. CARPENTER, PH.D.

Betsy Carpenter received her B.S. in Curriculum and Instruction in Biology and English from Texas A \& M University, her Master of Arts in Foreign Language Education/Linguistics and her Ph.D. in Special Education/Gifted and Talented Education from the University of Texas in Austin. She is the co-author of the Gifted and Talented Evaluation Scales (GATES) instrument for identifying gifted students

\section{MALLI TRAVIS}

Malli Travis received her BS in Multi-disciplinary Education from Texas Tech University. She teaches sixth grade science for Lubbock Independent School Districts and, along with Marti Smith, has been instrumental in developing the school-wide RoboRaiders LEGO Program at Hodges Elementary.

\section{MARTI SMITH}

Marti Smith received her Master of Arts in Teaching from Alaska Pacific Univeristy. She teaches sixth grade science of Lubbock Independent School Districts, and along with Malli Travis, has been instrumental in developing the school-wide RoboRaiders LEGO Program at Hodges Elementary

\section{ROBERT D. WALLER}

Robert Waller is an undergraduate student in computer science at Texas Tech University. Currently a Research Assistant for the Outdoor School, which focuses on experiential environmental education, his research focuses on hypertext systems and usability in software engineering. 